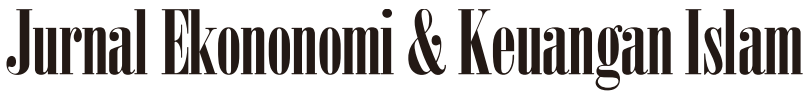

\author{
Available at http://journal.uii.ac.id/index.php/jeki
}

\section{Relevansi carbon emission disclosure dan karakteristik perusahaan pada perusahaan yang terdaftar di Jakarta Islamic Index}

\author{
Bayu Tri Cahya ${ }^{1}$, Umi Hanifah ${ }^{2}$ \\ ${ }^{1}$ Dosen Ekonomi Syariah STAIN KUDUS \\ *Corresponding author e-mail: cahyab380@gmail.com \\ ${ }^{2}$ Alumni Magister Akutansi Universitas Muhammadiyah Surakarta \\ e-mail: hanifahumi80@gmail.com
}

\section{Keywords: \\ company size, profitability, leverage, carbon emission disclosure and corporate value \\ DOI: \\ $\underline{\text { 10.20885/JEKI.vol3.iss2.art3 }}$}

\begin{abstract}
This study aimed to analyze the influence of corporate's characteristics toward carbon emission disclosure and disclosure of carbon emission effect toward firm value. Companies characteristics variable are proxied by firm size, profitability and leverage. The sampling method is a company incorporated in the Jakarta Islamic Index (JII) which amounted of 34 companies. The data used in this study is the annual reports of each companies obtained through the Indonesia Stock Exchange and the hypotheses were tested using multiple regression analysis. The results of this study indicate that the leverage proven that is has significant negative effect toward disclosure of carbon emissions, while profitability and size of the company doesn't have significant influence. Finally, the disclosure of carbon emissions are significantly influence the value of the company.
\end{abstract}

\begin{abstract}
Abstrak
Penelitian ini bertujuan untuk menganalisisis penngaruh karakteristik perusahaan terhadap pengungkapan emisi karbon dan pengungkapan efek emisi karbon terhadap nilai perusahaan. Variabel karakteristik perusahaan diproksikan oleh ukuran perusahaan, profitabilitas dan leverage. Metode pengambilan sampel penelitian ini adalah perusahaan yang tercatat dalam Jakarta Islamic Index (JII) yang berjumlah 34 perusahaan. Data yang digunakan adalah laporan tahunan masing-masing perusahaan yang diperoleh melalui Bursa Efek Indonesia (BEI) dan hipotesis diuji dengan menggunakan analisis regresi berganda. Hasil penelitian ini menemukan bahwa leverage terbukti berpengaruh negatif terhadap pengungkapan emisi karbon, sedangkan profitabilitas dan ukuran perusahaan tidak memiliki pengaruh, Dan, pengungkapan emisi karbon berpengaruh signifikan terhadap nilai perusahaan.
\end{abstract}

\section{Pendahuluan}

Menurut Friedman (1970) tanggung jawab sosial perusahaan adalah meningkatkan keuntungan bagi pemegang saham. Hal ini dikarenakan semboyan klasik yang dulunya diterapkan oleh banyak korporasi dimana waktu adalah uang, menganggap bahwa memenuhi kebutuhan pribadi atau perusahaan dengan sepenuhnya mengejar keuntungan adalah tujuan yang utama perusahaan. Selaras dengan pernyataan Friedman, jadi orientasi tanggung jawab (sosial) perusahaan pada waktu itu hanya pada profit maximation atau dengan istilah lain single bottom line. Aktifitas seperti itu didasarkan pada pemikiran filosofi dualism yang cenderung berorintasi pada pemikiran bahwa tugas korporasi adalah menghasilkan keuntungan dan kemudian persoalan sosial. Korporasi cenderung lebih mengutama target-target perusahaan yang menghasilkan maksimisasi profit dibanding dengan usaha untuk memperhatikan kepentingan masyarakat. Pada dasarnya pendiri perusahaan membuat ketentuan-ketentuan yang berhubungan dengan jalan perusahaan kepada direksi dan bawahannya hanya dimaksudkan untuk mendapatkan keuntungan secara maksimal (Wolfe, 1993).

Namun seiring dengan perkembangan jaman, nilai nilai-nilai masyarakat saat ini telah mengalami perubahan. Masyarakat yang mengalami masalah ketimpangan dan diskriminasi sosial akan mempunyai penilaian berbeda terhadap korporasi (Fajar, 2013). Bahwasanya bisnis bukan hanya sebagai entitas yang hanya bermaksud untuk mementingkan keuntungan semata tetapi juga mampu menangkap masalah-masalah masyarakat di lingkungannya (Daniri, 2006). Ketika perusahaan hanya fokus mendapatkan keuntungan untuk kepentingan pemegang saham, maka muncul kecenderungan bisnis yang dijalankan akan cenderung menyimpang. Pencemaran lingkungan dan sikap tidak peduli terhadap masyarakat sekitar adalah salah satu penyimpangan yang sering terjadi. Dengan begitu tanggung jawab sosial dari perusahaan sangat dibutuhkan. Perubahan lingkungan bisnis menyebabkan 
pelaku bisnis tidak hanya memikirkan cara untuk memaksimalkan laba tetapi juga memaksimalkan peran perusahaan bagi menyelesaikan masalah masyarakat

Elkington (1997) menyatakan bahwa perusahaan yang memperhatikan profit, people, planet (3P) memiliki peluang untuk bisa hidup lama. Dalam gagasan tersebut perusahaan harus memperhatikan aspek sosial dan lingkungannya selain aspek ekonomi (Wibisono, 2007; Rachman, Efendi dan Wicaksana, 2011). Dalam triple bottom line merumukan bahwa bukan hanya laporan keuangan, namun kepedulian sosial dan pelestarian lingkungan hidup menjadi bagian penting dari laporan perusahaan (Effendi, 2009). Masalah ini yang memunculkan wacana corporate social responsibility (CSR), dimana tanggung jawab perusahaan bukan hanya memaksimalkan keuntungan tetapi tanggung jawab sosial di lingkungan perusahaan (Kartini, 2013). CSR menjadi wacana umum dalam dunia bisnis di Indonesia karena semakin menglobalnya pemanfaatan CSR dalam bisnis (Fitria dan Hartanti, 2010). CSR berkembangan di Indonesia sebagai respon dunia usaha yang melihat aspek sosial dan lingkungan sebagai peluang untuk meningkatkan daya saing serta sebagai bagian dari pengelolaan resiko, menuju sustanaibility dari kegiatan usahannya (Kartini, 2013).

Isu global warming menjadi topik diskusi pengelolaan sumber daya alam di berbagai belahan dunia. Berbagai kalangan masyarakat dunia mulai menunjukkan kesadarannya terhadap kondisi lingkungan yang lebih baik melalui berbagai kegiatan (Dwijayanti, 2011). Ditandatanganinya Protokol Kyoto oleh beberapa negara merupakan amandemen terhadap Konvensi Rangka Kerja PBB terhadap Perubahan lklim (United Nation Framework Convention on Climate Change/UNFCCC) (Kardono, 2010), sebuah kesepakatan internasional tentang pemanasan global. Negara-negara yang meratifikasi protokol ini sepakat mengurangi emisi, pengeluaran karbon dioksida, lima gas rumah kaca lainnya serta bekerja sama dalam perdagangan emisi untuk mengatasi pemanasan global.

Indonesia telah meratifikasi Protokol Kyoto melalui UU No. 17 Tahun 2004 dalam rangka melaksanakan pembangunan berkelanjutan serta ikut serta dalam upaya menurunkan emisi Gas Rumah Kaca (GRK) global. Indonesia berkomitmen untuk menurunkan emisi karbon dapat ditunjukkan pada pasal 4 Perpres No. 61 Tahun 2011, yang menyatakan bahwa pelaku juga ikut terlibat dalam usaha upaya penurunan emisi GRK. Pengungkapan emisi GRK termasuk emisi karbon yang dilakukan oleh perusahaan sebagai pelaku usaha dapat diketahui dari pengungkapan emisi karbon (Carbon Emission Disclosure) (Jannah dan Muid, 2014). Peraturan Pemerintah No. 47 Tahun 2012 juga menunjukan bahwa PT untuk melakukan tanggung jawab sosial dan lingkungan atas segala aktifitas operasinya (Said, 2015).

Praktek pengungkapan tanggung jawab terhadap masalah lingkungan dan sosial di Indonesia diatur oleh Ikatan Akuntan Indonesia (IAI). PSAK No.1 paragraf 9 secara jelas menyarankan untuk mengungkapkan tanggung jawab terhadap masalah sosial kaitannya dengan persoalan lingkungan dan sosial. Karenanya, pengguna laporan keuangan tidak hanya untuk sebagian shareholder, namun juga untuk keseluruhan stakeholder lain seperti pelanggan, pemasok, karyawan, masyarakat dan lainnya.

Beberapa penelitian terdahulu terkait pengungkapan emisi karbon di Indonesia diantaranya yaitu, penelitian yang dilakukan Jannah dan Muid (2014), Pradini (2013), Ghozali (2015), Lorenzo (2009), Chu et al. (2013), Saka dan Tomoki (2014), Astuti dan Setiawati (2014), Suhardjanto dan Nugraheni (2012), Febrianti (2012), Safitri dan Wijaya (2015), Putri dan Raharja (2013). Penelitian ini mengacu pada temuan Jannah dan Muid (2014) dan Saka dan Tomoki (2014). Dimana penelitian tersebut mencoba menguji karakter perusahaan dengan emission carbon disclosure pada perusahaan syariah. Topik ini menarik untuk diamati karena berhubungan dengan tanggung jawab perusahaan terhadap lingkungan sekitar.

Hipotesis dalam penelitian ini adalah ketika pengungkapan social disclosure yang dilakukan perusahaan semakin baik maka stakeholder akan semakin puas sehingga akan memberi dukungan kepada perusahaan untuk menaikan kinerja dan pendapatan perusahaan. Data yang digunakan penelitian ini adalah perusahaan yang bergabung dalam Jakarta Islamic Index (JII) pada tahun 2012-2014. Pemilihan sampel pada perusahaan JII ini karena, perusahaan-perusahaan yang tergabung dalam JII hampir semua adalah perusahaan yang tergolong high profil, dimana perusahaan high profil dikategorikan sebagai perusahaan intensif dalam menghasilkan emisi karbon. Perusahaan intensif penghasil emisi karbon berpeluang besar dalam melakukan pengungkapan emisi karbon. Dimana pengungkapan emisi karbon ini sebagai bentuk tanggung jawab perusahaan atau kepedulian perusahaan terhadap lingkungan yang diakibatkan dari aktifitas operasinya.

Freedman (2015) mengembangkan konsep stakeholder untuk menjelaskan perilaku perusahaan (corporate behaviour) dan kinerja sosial (Ghomi dan Leung, 2013). Teori stakeholder mengatakan bahwa perusahaan harus mampu memberikan manfaat bagi stakeholdernya dan bukan hanya untuk entitas yang berhubungan dengan kepentingannya sendiri. Dengan demikian, dukungan stakeholder perusahaan sangat mempengaruhi keberadaan suatu perusahaan (Ghozali dan Chariri, 2007). Gray et al (1995) menunjukkan bahwa tanggung jawab sosial dan lingkungan akan mempengaruhi akuntabilitas stakeholder dan pemegang saham.

Menurut Gray (2001), stakeholder adalah pihak-pihak tertentu yang memiliki kepentingan pada perusahaan yang dapat mempengaruhi dan dipengaruhi oleh kegiatan perusahaan, para stakeholder antara lain masyarakat, 
karyawan, pemerintah, pasar, supplier, pasar modal dan lain-lain. Tujuan teori untuk stakeholder guna menciptakan nilai tambah bagi stakeholder karena stakeholder telah melakukan dukungan akan keberlangsungan hidup perusahaan. Stakeholder dapat menarik sumberdaya yang diperlukan perusahaan, apabila perusahaan tidak memberikan perhatian kepada stakeholder dan hal ini akan membahayakan keberlanjutan perusahaan. Oleh karenanya, perlu adanya pengelolaan stakeholder yang baik agar perusahaan dapat dukungan penuh dan tujuan perusahaan dapat tercapai. Peran pelaporan lingkungan adalah untuk menghindari setiap tindakan yang merugikan perusahaan.

Fokus teori legitimasi pada hubungan antara perusahaan dengan lingkungan masyarakat. Teori legitimasi menyatakan bahwa aktivitas perusahaan berdasarkan pada nilai kepercayaan, dan ketentuan sosial yang terdapat dalam masyarakat. (Ghozali dan Chariri, 2007). Teori legitimasi menjadikan perusahaan untuk menjalankan tanggung jawab terhadap lingkungan agar terlihat legitimate dihadapan masyarakat. Perusahaann cenderung akan bertanggung jawab terhadap lingkungannya karena sesuai dengan apa yang masyarakat inginkan. Masalah lingkungan yang disebabkan oleh operasi perusahaan tidak hanya terkait lingkungan sekitar perusahaan, namun sudah berkembang pada pemanasan global yang disebabkan oleh gas emisi yang dihasilkan dari kegiatan operasi perusahaan.

Pengungkapan emisi karbon merupakan salah satu bentuk tanggung jawab lingkungan yang dilakukan oleh perusahaan. Ancaman legitimasi perusahaan akan mendorong perusahaan untuk memasukkan lebih banyak informasi yang berhubungan dengan tanggung jawab sosial dalam laporan tahunan. Pada kenyataannya banyak perusahaan melakukan pengungkapan pada laporan untuk memperoleh legitimate bahwa perusahaan mampu bertahan hidup. Pengungkapan informasi emisi karbon dalam laporan keuangan adalah satu cara perusahaan untuk mempertahankan dan melegitimasi kontribusi perusahaan dari aspek ekonomi dan politis.

\section{Profitabilitas terhadap CED}

Profitabilitas sering dijadikan sebagai tolak ukur perusahaan dalam melakukan tanggung jawab terhadap lingkungan. Perusahaan yang memiliki kondisi keuangan yang baik lebih cenderung mengungkapkan informasi pada lingkungan. Menurut Choi et al (2013), perusahaan yang memiliki kondisi keuangan yang baik lebih mampu membayar sumber daya tambahan manusia atau keuangan untuk melakukan pelaporan emisi karbon dibanding perusahaan dengan kondisi keuangan yang buruk. Pada perusahaan yang memiliki kondisi keuangan yang baik pelaporan emisi karbon merupakan bentuk penyelesaian masalah yang efektif atas tekanan lingkungan terkait kegiatan operasinya. Perusahaan yang memiliki kondisi keuangan yang buruk, pelaporan emisi karbon dinilai sebagai biaya tambahan yang akan menambah beban operasional perusahaan semakin meningkat. Berdasarkan penjelasan di atas maka hipotesis penelitian ini adalah: $\mathrm{H}_{1}$ : profitabilitas berpengaruh terhadap carbon emission disclosure.

\section{Profitabilitas terhadap CED}

Ukuran perusahaan mempunyai hubungan yang positif dengan pengungkapan emisi karbon, semakin besar suatu perusahaan maka tekanan sosial yang diterima lebih besar dalam pengungkapan sukarela dibanding perusahaan kecil (Choi et al, 2013). Semakin besar ukuran suatu perusahaan, maka akan lebih terlihat kegiatan operasinya begitu juga dengan kontribusi terhadap lingkungan sekitar dan hal tersebut dapat digunakan oleh pihak tertentu untuk menekan perusahaan dalam memberikan perhatian terkait masalah lingkungan.

Penelitian Freedman \& Jaggi (2005) juga menyatakan bahwa perusahaan yang besar lebih mengungkapkan secara detail informasi terkait polusi. Azaria \& Achyani (2015) mendapatkan hasil bahwa ukuran perusahaan berpengaruh terhadap tingkat keluasan pengungkapan informasi dalam laporan tahunan perusahaan. Begitu pula penelitian yang dilakukan oleh Wang et al (2013) menyatakan bahwa tekanan sosial dan politik akan dihadapi perusahaan besar daripada perusahaan kecil maka maka perusahaan besar akan peningkatan pengungkapan informasi untuk membangun citra sosial yang baik. Citra sosial tersebut dijadikan perusahaan untuk mendapatkan legitimasi dari masyarakat atau komunitas dimana perusahaan itu beroperasi (Jannah \& Muid, 2013). Berdasarkan uraian tersebut, maka hipotesis dalam penelitian ini adalah: $\mathrm{H}_{2}$ : ukuran perusahaan berpengaruh terhadap carbon emission disclosure.

\section{Leverage terhadap CED}

Pengungkaan emisi karbon yang dilakukan perusahaan kondisi keuangan buruk akan menjadikan kekhawatiran debt holders, suppliers, dan customer (Choi, et al 2013). Perusahaan dengan Leverage yang tinggi akan lebih memilih untuk tidak melakukan pengungkapan emisi karbon dikarenakan pengungkapan akan menambah extra cost bagi perusahaan. Perusahaan lebih memilih untuk melakukan penghematan dana untuk melunasi semua kewajiban dibanding melakukan pengungkapan (Luo et al, 2013). 
Teori stakeholder menyebutkan jika leverage perusahaan semakin tinggi maka perusahaan akan memiliki tanggung jawab terhadap kreditur akan semakin tinggi pula, sehingga perusahaan dituntut untuk memanfaatkan sumber dana yang ada guna melunasi hutangnya daripada digunakan untuk pengungkapan emisi karbon, karena dalam melakukan pengungkapan maka akan menjadikan biaya yang lebih besar dan menjadikan beban perusahaan semakin besar (Choi, et al 2013). Leverage dapat berpengaruh terhadap keuangan perusahaan. Dalam penelitian Luo et al (2013) mengungkapkan bahwa perusahaan dengan leverage yang tinggi memiliki dana yang sedikit untuk melakukan pengungkapan karena besarnya beban hutang yang ditanggung. Dari uraian diatas maka maka hipotesis dalam penelitian ini adalah: $\mathrm{H}_{3}$ : leverage berpengaruh terhadap carbon emission disclosure

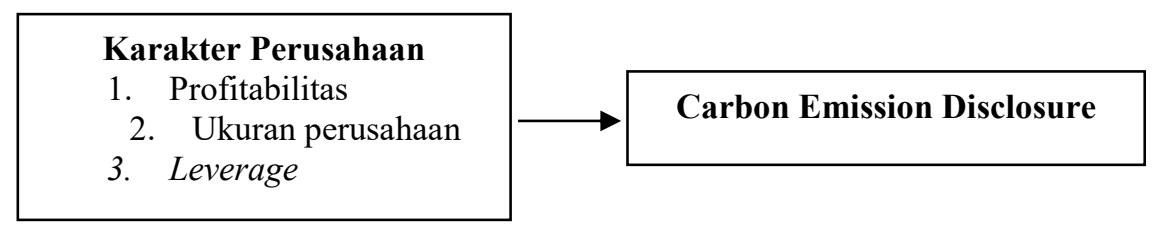

Gambar 1. Kerangka Pemikiran Teoritis

\section{Metode Penelitian}

Variabel independen dalam penelitian ini adalah profitabilitas, ukuran perusahaan, leverage dan carbon emission disclosure. Profitabilitas diukur dari laba sebelum pajak perusahaan. Ukuran perusahaan dihitung dari total aset perusahaan. Leverage merupakan rasio total utang dibagi dengan total aset. Carbon emission disclosure dihitung dengan mengunakan metode pengukurannya content analysis yaitu, melakukan pengukuran dengan cara membaca laporan tahunan dan sustainability report perusahaan sampel untuk mengetahui sejauh mana perusahaan melakukan pengungkapan emisi karbon. Sedangkan variabel dependen dalam penelitian ini adalah carbon emission disclosure.

Populasi penelitian ini adalah perusahaan yang terdaftar di Bursa Efek Indonesia (BEI) yang masuk dalam Jakarta Islamic Index (JII) periode 2012-2014. Metode pengumpulan sampel mengunakan teknik pengambilan sampel bertujuan (purposive sampling). Kriteria pemilihan sampel penelitian adalah sebagai berikut : 1) Perusahaan yang tergabung dalam JII pada tahun 2012-2014. 2) Tersedia laporan keuangan perusahaan secara lengkap selama periode pengamatan (2012-2014). 3) Laporan keuangan perusahaan disajikan dalam bentuk satuan Rupiah.4) Sampel penelitian menyajikan pengungkapan emisi karbon dalam laporan tahunannya (minim satu kebijakan terkait dengan emisi karbon/ gas rumah kaca atau pengungkapan minimal satu item emisi karbon). Adapun model persamaan adalah sebagai berikut:

$\mathrm{CED}=\alpha+\beta 1 \mathrm{UP}+\beta 2 \mathrm{P}+\beta 3 \mathrm{~L}+\varepsilon$

Dimana CED adalah Carbon emission disclosure, $\mathrm{P}$ adalah profitabilitas, UP adalah ukuran Perusahaan, L adalah leverage, $\alpha$ adalah konstanta dan $\beta 1 \ldots \beta 4$ adalah koefisien TP, P, UP, L.

\section{Hasil dan Pembahasan}

Objek dari penelitian ini adalah perusahaan yang tercatat di BEI yang masuk dalam Jakarta Islamic Indeks (JII) periode 2012 - 2014. Pengumpulan sampel pada penelitian ini menggunakan metode purposive sampling. Sampel berjumlah 34 perusahaan dan mengenai pengambilan sampel ditujukan pada tabel di bawah ini.

Tabel 1. Populasi dan Sampel Penelitian Tahun 2012-2014

\begin{tabular}{lc}
\hline \multicolumn{1}{c}{ Keterangan } & Jumlah \\
\hline Jumlah Perusahaan yang terdaftar pada JII selama periode 2012-2014 & 90 \\
Perusahaan yang tidak secara konsisten masuk dalam indek JII selama satu tahun (periode) & $(8)$ \\
Perusahaan yang tidak meng expose laporan annual report nya & $(1)$ \\
Perusahaan yang tidak menggunakan unit moneter rupiah dalam laporan tahunan perusahaannya & $(16)$ \\
Outlier Data & $(31)$ \\
Jumlah Sampel Perusahaan & $\mathbf{3 4}$ \\
\hline
\end{tabular}

Sumber:Data sekunder yang diolah, 2016 
Tabel 2. Hasil Statistik Deskriptif

\begin{tabular}{|c|c|c|c|c|c|c|}
\hline & $\mathrm{N}$ & & Minimum & Maximum & Mean & Std. Deviation \\
\hline SIZE & & 34 & 5827294,00 & 140895000,0 & 57032760,38 & 34220244,63 \\
\hline PROFIT & & 34 & 485106,00 & 28784000,00 & 5453636,059 & 7324540,453 \\
\hline LEVERAGE & & 34 & 0,14 & 0,81 & 0,4800 & 0,15163 \\
\hline FV & & 34 & 0,45 & 6,32 & 1,7332 & 1,25548 \\
\hline INDEKSECD & & 34 & 0,06 & 0,67 & 0,1961 & 0,13963 \\
\hline Valid N (listwise) & & 34 & & & & \\
\hline
\end{tabular}

Sumber: Data sekunder yang diolah, 2016

Pengujian hasil dilakukan dengan analisis regresi berganda. Gambaran lebih jelas mengenai hasil regresi akan dijelaskan pada tabel 3.

Tabel 3. Hasil Pengujian Hipotesis

\begin{tabular}{lc}
\hline Pengujian Hipotesis & Hasil Pengujian \\
\hline $\begin{array}{l}\text { Uji Koefisien Determinasi } \\
\left(\text { Adjusted R } \mathbf{~}^{\mathbf{2}}\right.\end{array}$ & 0,279 \\
Uji Signifikasi Simultan F & \\
$\mathrm{F}$ & 5,263 \\
Sig. & 0,005 \\
Uji Signifikansi Parsial & \\
(Uji-T) & \\
Koefisien kesalahan & Profit $1,654 \mathrm{E}-9$ \\
standar & Leverage $-0,386$ \\
& Logsize 0,084 \\
$\mathrm{t}$ & \\
& Profit 0,388 \\
& Leverage $-2,595$ \\
& Logsize 0,959 \\
Sig. & Profit 0,701 \\
& Leverage 0,015 \\
& Logsize 0,345 \\
\hline
\end{tabular}

\section{Pengaruh Profitabilitas terhadap CED}

Hasil pengujian terhadap variabel profitabilitas menunjukkan bahwa profitabilitas tidak mendukung teori legitimasi dan stakeholder. Perusahaan dengan tingkat profitabilitas tinggi akan dapat mengungkapkan informasi bahwa mereka bertindak dengan baik atas tekanan lingkungan secara efektif dengan menyelesaikan masalah dengan cepat. Demikian juga dengan teori stakeholder yang menyatakan bahwa perusahaan dengan profitabilitas yang tinggi akan memiliki kemampuan untuk mempengaruhi hubungan perusahaan dengan stakeholder (Ghozali \& Chariri 2007).

Tidak adanya hubungan antara profitabilitas dengan pengungkapan informasi ini disebabkan karena profit tinggi dan aset yang dimiliki berasal dari hutang, maka perusahaan akan memutuskan untuk tidak melakukan pengeluaran biaya untuk pengungkapan sukarela melainkan lebih memilih untuk membayarkan kepada para pemberi pinjaman sebagai bentuk kewajiban yang harus dilakukan. Hasil ini sesuai dengan penelitian Luo et al (2013) yang menyatakan bahwa beban membayar hutang dan bunga akan membatasi perusahaan untuk dapat melakukan stategi pengurangan karbon dan pengungkapannya.

Berbeda dengan penelitian Jannah dan Muid (2013) yang mengungkapkan bahwa profitabilitas berpengaruh positif dengan pengungkapan emisi karbon. Demikian juga hasil penelitian Choi et. al (2013) yang menunjukkan bahwa profitabilitas berpengaruh positif dengan pengungkapan emisi karbon.

\section{Pengaruh Ukuran Perusahaan terhadap CED}

Ukuran perusahaan tidak mendukung teori legitimasi yang menyatakan bahwa ukuran perusahaan besar akan cenderung memiliki tekanan yang lebih tinggi dalam hal masalah lingkungan, sehingga perusahaan cenderung 
untuk meningkatkan respon terhadap lingkungan dan perusahaan besar lebih terdorong untuk memberikan pengungkapan yang berkualitas

Hasil penelitian ini berbeda dengan penelitian Jannah dan Muid (2013) yang menyatakan bahwa ukuran perusahaan mempunyai hubungan positif dengan carbon emission disclosure. Demikian juga hasil penelitian Lorenzo et al (2009) yang menemukan bahwa size (ukuran perusahaan) berpengaruh terhadap greenhouse gas emission disclosure. Penelitian Freedman dan Jaggi (2005) menyatakan bahwa perusahaan besar memiliki kemampuan untuk mengungkapkan secara detail informasi terkait pencemaran, demikian juga dengan penelitian Choi et al (2013) menemukan bahwa ukuran perusahaan mempengaruhi carbon emission disclosure. Hal tersebut menyebabkan perusahaan lebih diuntungkan dengan memberikan informasi kepada investor dan stakeholder pengungkapkaan sukarela mengenai lingkungan.

\section{Pengaruh Leverage terhadap CED}

Hasil regresi menunjukkan bahwa leverage berpengaruh terhadap pengungkapan emisi karbon. Namun, ternyata ukuran perusahaan dan profitabilitas berpengaruh terhadap pengungkapan emisi karbon. Hasil pengujian terhadap variabel leverage sesuai dengan teori stakeholder bahwa sesungguhnya stakeholder dapat mempengaruhi pengunaan sumber-sumber ekonomi yang dipakai perusahaan. Oleh karenanya powerstakeholder ditentukan dari besar kecilnya power yang dimilikinya (Ghozali dan Chariri, 2007).

Pada saat stakeholder mengendalikan sumber ekonomi perusahaan yang penting, maka perusahaan cenderung bereaksi untuk memuskan segala keinginan stakeholder. Adapun cara perusahaan untuk memanage stakeholder tergantung perusahaan dalam memilih stateginya (Ulman, 1985 dalam Ghozali dan Chariri, 2007). Berhubungan dengan pengungkapan emisi karbon, perusahaan me-manage stakeholder terkait dengan biaya termasuk pengurangan emisi karbon. Keadaan ini mengindikasikan bahwa leverage dapat mempengaruhi keuangan suatu perusahaan. Menurut Luo et al (2013), kewajiban yang besar untuk memenuhi pembayaran hutang dan bunga akan membatasi perusahaan untuk mencari cara untuk pengurangan karbon dan pengungkapannya. Perusahaan yang memiliki tingkat leverage tinggi akan berhati-hati dalam melakukan pengeluaran biaya.

Hasil penelitian ini menyatakan bahwa leverage berpengaruh negatif terhadap pengungkapan emisi karbon, artinya semakin tinggi tingkat leverage maka semakin rendah pengungkapan emisi karbon. Hasil ini dapat disimpulkan bahwa ketika leverage tinggi maka perusahaan cenderung tidak melakukan pengungkapan emisi karbon. Hal ini terjadi karena dalam melakukan pengungkapan maka perusahaan akan mengeluarkan biaya lebih, sedangkan perusahaan masih memiliki kewajiban hutang yang harus dibayar. Hasil penelitian ini tidak sejalan dengan penelitian Jannah dan Muid (2013) dimana memiliki pola positif yang mengungkapkan bahwa leverage mempunyai hubungan positif dengan pengungkapan lingkungan, yaitu pengungkapan emisi karbon.

\section{Kesimpulan}

Penelitian ini mengungkapkan pengaruh karakteristik perusahaan, seperti profitabilitas, ukuran perusahaan dan leverage) terhadap carbon emission disclosure dan pengaruh carbon emission disclosure terhadap nilai perusahaan. Analisis menunjukkab bahwa emisi karbon berasal dari laporan tahunan (annual report) maupun laporan keberlanjutan (sustainability report) perusahaan. Berdasarkan analisis yang telah dilakukan dalam penelitian ini, dapat disimpulkan bahwa; 1) ukuran perusahaan dan profitabilitas tidak berpengaruh terhadap carbon emission disclosure, sedangkan leverage berpengaruh negatif terhadap carbon emission disclosure. Hal ini menunjukkan bahwa pelaku pasar modal memperhatikan tingkat emisi karbon perusahaan untuk melakukan investasi

\section{Daftar Pustaka}

Astuti, L \& Setiawati, E. (2014). Analisis Pengaruh Profitabilitas, Kebijakan Deviden, Kebijakan Hutang, Dan Kepemilikan Manajerial terhadap Nilai Perusahaan (Studi Empiris Pada Perusahaan Manufaktur Yang Terdaftar Di Bursa Efek Indonesia Tahun 2010-2012). Seminar Nasional dan Call For Paper. Program Studi Akuntansi-FEB UMS.

Azaria, A \& Achyani, F. (2015). Faktor-Faktor yang Mempengaruhi Tingkat Keluasan Pengungkapan Informasi Dalam Laporan Tahunan. Prosiding: Menakar Masa Depan Profesi Memasuki MEA 2015 Menuju Era Crypto Economic. Universitas Muhammadiyah Surakarta. Surakarta

Choi, B. B, Lee, D \& Psaros, J. (2013). An Analysis of Australian Company Carbon Emission Disclosures. Pasific Accounting Review, 25(1), 58-79.

Chu, L.C, Chatterjee, B \& Brown. A, (2012). The Current Status of Greenhouse Gas Reporting by Chinese Companies. Managerial Auditing Journal, 28 (2), 114 - 139. 
Chung K.H. and Pruitt S., (1994), A Simple Approximation of Tobin's Q, Financial Management. 23 (3),70-74.

Daniri, M. A (2015). Standarisasi Tanggung Jawab Sosial Perusahaan. Sambutan Menteri Negara Lingkungan Hidup pada Seminar Sehari A Promise of Gold Rating: Sustainable CSR. Diambil dari www.menlh.go.id. Diakses pada tanggal 23 Mei 2015

Dwijayanti, S,P.F. (2011). Manfaat Penerapan Carbon Accounting di Indonesia. Jurnal Akuntansi Kontemporer, $3(1), 79-92$

Effendi, M. A. (2016). The Power of Good Corporate Governance Teori dan Implementasi. Jakarta: Salemba Empat.

Elkington, J. (1997). Canibal With Work: The Triple Botoom Line in $21^{\text {st }}$ Century Business. Gabriola Island, BS: New Society Publisher.

Fajar, M. (2013). Tanggung Jawab Sosial Perusahaan di Indonesia. Yogyakarta: Pustaka Pelajar.

Febrianti, M. (2012). Faktor-Faktor yang Mempengaruhi Nilai Perusahaan pada Industri Pertambangan di Bursa Efek Indonesia. Jurnal Bisnis dan Akuntansi, 14 (2), 141-156.

Fitria, S \& Hartanti. (2010). Islam dan Tanggung Jawab Sosial : Studi Perbandingan Pengungkapan berdasarkan Global Reporting Initiative Indeks dan Islamic Social Reporting Indeks. Simposium Nasional Akuntansi XIII. Purwokerto.

Freedman, M \& Jaggi, B. (2005). Global Warming, Commitment to the Kyoto Protocol, and Accounting Disclosures by the Largest Global Public Firms from Polluting Industries, The International Journal of Accounting, 40 (3), 215-232.

Friedman, M (1970). The Social Responsibility of Business is to Increase its Profits, The New York Times Magazine, September, http://www.colorado.edu/studenggroups/libertarians /issues/friedman-soc-respbusiness.html.

Ghomi \& Leung, (2013). An Empirical Analysis of the Determinants of Greenhouse Gas Voluntary Disclosure in Australia. Accounting and Finance Research, 2 (1), 110-127.

Ghozali, I dan Chariri, A. (2007). Teori Akuntansi. Semarang: Badan Penerbit Universitas Diponegoro.

Gray, R, Kouhy, R \& Lavers, S (1995). Corporate Social and Environmental Reporting: A Review of Literature and a Longitudinal Study of UK Disclosure. Accounting, Auditing, and Accountability Journal, 8 (2), 47 76.

Gray, R. (2001). Thirty Years of Social Accounting, Reporting, and Auditing: what (if anything) have we learnt?.Business Ethics: A European Review, 10 (1), 9-15.

Jannah, R. \& Muid, D. (2014). Analisis Faktor-Faktor Yang Mempengaruhi Carbon Emission Disclosure pada Perusahaan di Indonesia. Diponegoro Journal of Accounting, 3 (2), 2337-3806

Kardono, (2010). Memahami Perdagangan Karbon. Info PUSTANLING, 12 (1), 2-15.

Kartini, D. (2013). Corporate Social Responsibility: Tranformasi Konsep Sustainablity Management dan Implementasi di Indonesia. Bandung: Refika Aditama.

Lorenzo, J. P, Luiz R, , Isabel G \& Isabel M. G. (2009). Factors Influencing the Disclosure of Greenhouse Gas Emissions in Companies World-Wide. Journal of Management Decisions, 47, 1133-1157.

Luo, L, Tang, Q, \& Lan, Y. (2013). Comparison of Propensity for Carbon Disclosure between Developing and Developed Countries. Accounting Research Journal, 26 (1), 6-34.

Meek, G.K., Robert, C.B \& Gray, S,J (1995), Factors Influencing Voluntary Annual Report Disclosure by U.S., U.K. and Continental European Multinational Corpo-rations, Journal of International Business Studies, 26 (3), 555-571.

Pradini, H. S \& Kiswara, E (2013). The Analysis of Information Content towards Greenhouse Gas Emissions Disclosure in Indonesia's Companies, Diponegorao Journal of Accounting, 2(2), 1-12

Putri, H, C, M \& Raharja, S (2013). Pengaruh Corporate Social Responsibility terhadap Nilai Perusahaan dengan Kepemilikan Manajerial sebagai Variabel Moderating. Diponegoro Journal of Accounting, 2 (3), 1-15

Rachman, N. M. (2011). Panduan Lengkap Perencanaan CSR. Jakarta: Niaga Swadaya.

Safitri, Y \& Wijaya, T. (2015). Analisis Pengaruh Leverage Ratio, DPR, EPS dan Kepemilikan Manajerial terhadap Nilai Perusahaan. Diambil dari http://eprints.mdp.ac.id/1509/1/Jurnal\%20Yuliana.pdf

Said, A. L. (2015) Corporate Social Responsibility dalam Perspektif Governance. Yogyakarta: Budi Utama. 
Saka, C \& Oshika, T. (2014). Disclosure Effects, Carbon Emissions and Corporate Value. Management and Policy Journal.5 (1), 22-45.

Suhardjanto, D \& Nugraheni, S (2012). Pengaruh Corporate Social Responsibility (CSR) Disclosure terhadap Nilai Perusahaan (Studi Empiris di Bursa Efek Indonesia). Jurnal Akuntansi. 16 (2), 162-175

Wang, J, Song, L, \& Yao. (2013). The Determinants of Corporate Social Responsibility Disclosure: Evidence From China. The Journal of Applied Business Research, 29(6), 1833-1847.

Wibisono, Y. (2007). Membedah Konsep dan Aplikasi Corporate Social Responsibilitie. Gresik: Fascho Publishing.

Wolfe, A.(1993). The Modern Corporation: Private Agent or Public Actor?, Washington and Lee Law Review, 50 (4), 1673-1696 